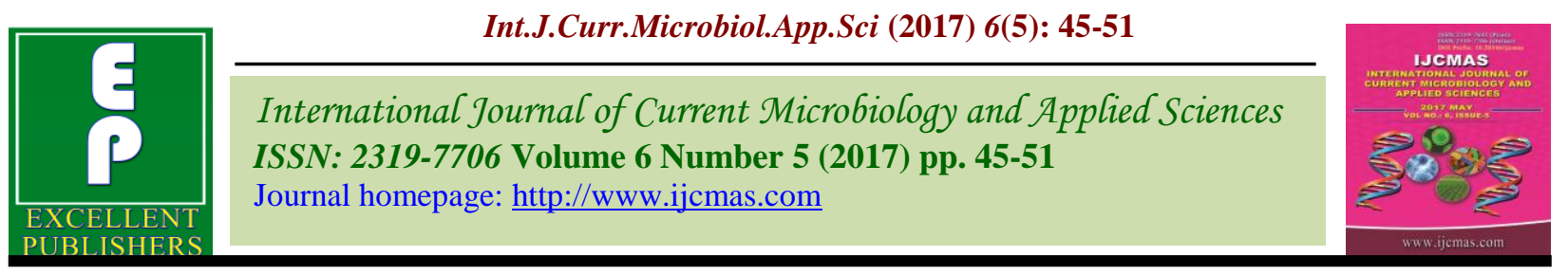

Original Research Article

https://doi.org/10.20546/ijcmas.2017.605.006

\title{
Effect of Copper Contamination on Soil Biochemical Activity and Performance of Rice (Oryza sativa L.)
}

\author{
T. Prabhakar Reddy*, D. Vijaya Lakshmi, J. Kamalakar and Ch. Sambasiva Rao \\ Department of Soil Science and Agricultural Chemistry, \\ Regional Sugarcane and Rice Research Station, PJTSAU, Rudrur, Nizamabad \\ Professor Jayashankar Telangana State Agricultural University, Telangana, India \\ *Corresponding author
}

\begin{tabular}{|c|c|}
\hline & A B S T R A C T \\
\hline & \multirow{7}{*}{$\begin{array}{l}\text { A pot culture experiment was carried out to determine the effect of soil contamination with } \\
\mathrm{CuSO}_{4} 5 \mathrm{H}_{2} \mathrm{O} \text { in different concentrations on the activity of soil enzymes (Dehydrogenases, } \\
\text { Urease, Acid and Alkaline Phosphatase) and dry matter yield of rice. The experiment was } \\
\text { conducted in completely randomized design comprising } 6 \text { levels of } \mathrm{Cu}(0,50,100,150 \text {, } \\
200 \text { and } 250 \mathrm{mg} \mathrm{kg}^{-1} \text { soil). Soil contamination with } \mathrm{Cu} \text { also had a negative effect on the dry } \\
\text { matter yield and yield attributes of rice. Toxic activity of } \mathrm{Cu} \text { on rice appeared at the lowest } \\
\text { dose }\left(100 \mathrm{mg} \mathrm{kg}^{-1}\right) \text {, and higher doses of Cu were found to intensify the effect. The enzyme } \\
\text { activity in the soil samples was determined at } 30,60,90 \mathrm{DAS} \text { and at harvest. The enzyme } \\
\text { activity increased up to } 30 \mathrm{DAS} \text { which later decreased to harvest. The results indicated } \\
\text { that, soil contamination with } \mathrm{CuSO}_{4} 5 \mathrm{H}_{2} \mathrm{O} \text { of } 100,150,200 \text { and } 250 \mathrm{mg} \mathrm{Cu} \mathrm{kg} \mathrm{kg}^{-1} \text { soil } \\
\text { significantly inhibited the activity of dehydrogenases, urease, acid and alkaline } \\
\text { phosphatases. The soil enzymes can be arranged in terms of their sensitivity to Cu as } \\
\text { follows: dehydrogenases }>\text { urease }>\text { alkaline phosphatase }>\text { acid phosphatase. } \\
\text { Dehydrogenases and urease appeared to be better indicators of soil contamination with Cu, } \\
\text { as their activity was more strongly inhibited by Cu than the activity of phosphatases. }\end{array}$} \\
\hline Keywords & \\
\hline Copper, & \\
\hline $\begin{array}{l}\text { Rice, Biochemical } \\
\text { activity, Nutrient } \\
\text { concentration. }\end{array}$ & \\
\hline Article Info & \\
\hline $\begin{array}{l}\text { Accepted: } \\
\text { 04 April } 2017 \\
\text { Available Online: } \\
10 \text { May } 2017\end{array}$ & \\
\hline & \\
\hline
\end{tabular}

\section{Introduction}

Copper $(\mathrm{Cu})$ is an essential element for regular functioning of organisms. It plays significant role in number of physiological processes like photosynthetic and respiratory electron transport chains, $\mathrm{N}$ fixation, protein metabolism, cell wall metabolism, anti oxidant activity, fatty acid metabolism and harmone perception. However, excessive amounts of $\mathrm{Cu}$ in the root zone inhibit growth, chlorosis of leaves and limited germination of seeds. The higher absorption of $\mathrm{Cu}$ contributes to metabolism disturbances, damages to plasma membrane permeability, membrane integrity and induces general symptoms of senescence.

$\mathrm{Cu}$ is extensively used in agriculture in the form of $\mathrm{Cu}$ containing fertilizers, fungicides, bactericides, algicides and in the form of metal contaminated composts, sewage sludge as well as feed additive in antibiotics, drugs, growth promoters etc. Its abundance in the earth crust (24-55 $\mu \mathrm{g} \mathrm{g}^{-1}$ ) and soil (20-30 $\mu \mathrm{g}$ $\mathrm{g}^{-1}$ ) makes it pollution problem in most agricultural soils (Pendias and Pendias, 2001). $\mathrm{Cu}$ enter into the soil through various sources 
affecting soil microbial properties responsible for nutrient recycling and enzyme activities within soil-plant ecosystem. Keeping in view the effect of $\mathrm{Cu}$ contamination on soil biochemical activity and growth of rice, an experiment was conducted to determine the effect of soil contamination with $\mathrm{CuSO}_{4}$ $5 \mathrm{H}_{2} \mathrm{O}$ in different concentrations on the activity of soil enzymes (Dehydrogenases, Urease, Acid and Alkaline Phosphatase) and dry matter yield of rice.

\section{Materials and Methods}

A pot culture experiment was conducted in earthen pots contains $5 \mathrm{~kg}$ of well mixed air dried red sandy loam soil. The rice var. BPT 5204 used as test crop. Carefully selected uniform sized seeds were directly sowed in each pot. The experiment consisting of six treatments comprising 6 levels of $\mathrm{Cu}(0,50$, $100,150,200$ and $250 \mathrm{mg} \mathrm{kg}^{-1}$ soil). $\mathrm{Cu}$ treatments were given through addition of varying amounts of $\mathrm{CuSO}_{4} \cdot 5 \mathrm{H}_{2} \mathrm{O}$. The recommended doses of fertilisers were applied uniformly to all the treatments. The treatments were replicated five times in a completely randomized design. The experimental soil is sandy loam in texture, slightly alkaline $(\mathrm{pH} 7.2)$ in reaction, non saline $\left(0.18 \mathrm{dSm}^{-1}\right)$, low in organic carbon (0.43 percent) and available $\mathrm{N}\left(196.5 \mathrm{~kg} \mathrm{ha}^{-1}\right)$, medium in available $\mathrm{P}_{2} \mathrm{O}_{5}\left(29.21 \mathrm{~kg} \mathrm{ha}^{-1}\right)$ and $\mathrm{K}_{2} \mathrm{O}\left(293.5 \mathrm{~kg} \mathrm{ha}^{-1}\right)$ and having sufficient amounts of micronutrients.

Plant samples collected at harvest was dried in an oven and analyzed the contents of N, P, $\mathrm{K}, \mathrm{S}, \mathrm{Fe}, \mathrm{Mn}, \mathrm{Zn}$ and $\mathrm{Cu}$. Dry weight of root and shoot was determined. Oven dried plants were digested in appropriate acid mixtures and the nutrient contents were measured. Using the acid digest, nitrogen was determined by micro-Kjeldahl method and phosphorus was determined by vanadomolybdate method measuring the absorbance at $460 \mathrm{~nm}$ by spectrophotometer. $\mathrm{K}, \mathrm{Na}, \mathrm{Ca}$ and $\mathrm{Mg}$ were determined by flame photometer. $\mathrm{Fe}, \mathrm{Mn}, \mathrm{Zn}$ and $\mathrm{Cu}$ were determined by atomic absorption spectrophotometer (AAS). The statistical analysis of the experimental data was carried out as per the procedure given by Gomez and Gomez (1984).

The enzyme activity in the soil samples was determined at 30, 60, 90 DAS and at harvest. Urease activity was assayed by qualifying the rate of release of $\mathrm{NH}_{4}{ }^{+}$from the hydrolysis of urea as described by Tabatabai and Bremner (1972) but with some modifications as suggested by Sankara Rao (1989). Dehydrogenase activity was assayed by quatifying the $\mathrm{mg}$ of TPF (2,3,5-tri-phenyl formazon) produced and exposed as $\mathrm{g}^{-1}$ soil $^{-1} \mathrm{~d}^{-1}$ as described by Casida et al., (1964). The acid and alkaline phosphatase activity was assayed by quantifying the amount of P-nitrophenol released and expressed as $\mu \mathrm{g}$ of P-nitrophenol released $\mathrm{g}^{-1}$ soil $^{-1} \mathrm{~d}^{-1}$ as described by Tabatabai and Bremner (1969).

\section{Results and Discussion}

\section{Dry matter yield and yield attributes of rice}

The results indicated that application of $\mathrm{Cu}$ slightly increased the root and shoot dry weight at lower concentrations, while excess $\mathrm{Cu}$ reduced the biomass (Table 1). Moreover, high concentrations of $\mathrm{Cu}$, the root and shoot elongation was poor with a concomitant decrease in root and shoot drymatter (Bouazizi et al., 2008; Ahsan et al., 2007). Significant increase in the growth, possibly due to $\mathrm{Cu}$ is required by plants in trace amount (Reichman, 2002). The inhibitory action of excess $\mathrm{Cu}$ in root and shoot length may be due to reduction in cell division, toxic effect of heavy metal on photosynthesis, respiration and protein synthesis. 


\section{Plant nutrient concentration (\%)}

The effect of $\mathrm{Cu}$ on various micronutrient contents like NPK of rice plant at harvest indicated that, nutrient contents increased at lower level $\left(50 \mathrm{mg} \mathrm{kg}^{-1}\right)$ and decreased to higher level (100 to $250 \mathrm{mg} \mathrm{kg}^{-1}$ ). The inhibitory effect of $\mathrm{Cu}$ on macronutrient content of rice plant could be attributed to poor development of roots, reduced rate of protein metabolism which results in decreased uptake of macronutrients from the soil. High concentration of $\mathrm{Cu}$ suppresses the $\mathrm{P}$ metabolism by lowering the content of inorganic $\mathrm{P}$. The decrease of $\mathrm{K}$ content of rice due to elevated levels of $\mathrm{Cu}$ may be attributed to deterioration of physiological state of the plant which intern reduction in $\mathrm{K}$ uptake. The decrease in potassium content of rice due to elevated level of $\mathrm{Cu}$ is in conformity with the reports of Lidon and Henriques (1993) and Ouzounidou (1994).

Increased $\mathrm{Cu}$ content of soil slightly decreased the micronutrient content of rice (Table 2). However lower levels of $\mathrm{Cu}(50 \mathrm{mg}$ $\mathrm{kg}^{-1}$ ) increases the $\mathrm{Fe}, \mathrm{Mn}$ and $\mathrm{Zn}$ content of rice plant over control. Excess $\mathrm{Cu}$ antagonistically affects the translocation of $\mathrm{Fe}$, and $\mathrm{Zn}$ from the stem to the leaves and increased the competition of $\mathrm{Cu}$ with $\mathrm{Fe}, \mathrm{Mn}$ and $\mathrm{Zn}$. The decrease in Mn content may be due to increased competition of $\mathrm{Cu}$ with $\mathrm{Mn}$ for transport sites in plasma lemma (Wang et al., 2009). Application of $\mathrm{Cu}$ did not affect concentration of $\mathrm{Zn}$, but higher levels causes antagonistic effect.

\section{Soil enzyme activities}

The results indicated that the enzyme assayed at different growth stages of rice showed that there was increase in enzyme activity up to 30 DAS which later decreased to harvest. Soil contamination with $\mathrm{CuSO}_{4} 5 \mathrm{H}_{2} \mathrm{O}$ of 100,150 , 200 and $250 \mathrm{mg} \mathrm{Cu} \mathrm{kg}^{-1}$ soil significantly inhibited the activity of dehydrogenases, urease, acid and alkaline phosphatases. The soil enzymes can be arranged in terms of their sensitivity to $\mathrm{Cu}$ as follows: dehydrogenases $>$ urease > alkaline phosphatase > acid phosphatase.

Table.1 Effect of $\mathrm{Cu}$ on dry matter yield and yield attributes of rice

\begin{tabular}{|c|c|c|c|c|}
\hline \multirow{2}{*}{$\begin{array}{c}\text { Cu added } \\
\text { in the soil } \\
\left(\mathrm{mg} \mathrm{kg}^{-1}\right)\end{array}$} & \multicolumn{2}{|c|}{ Dry matter yield $\left(\mathrm{g} \mathrm{hill}^{-1}\right)$} & \multirow{2}{*}{$\begin{array}{c}\text { No. of } \\
\text { effective }\end{array}$} & $\begin{array}{c}\text { No. of } \\
\text { matured } \\
\text { tillers hill }^{-1}\end{array}$ \\
\cline { 2 - 3 } grains per $_{\text {panicle }^{-1}}$ \\
\hline 0 & 1.53 & 4.35 & 06 & 163 \\
\hline 50 & 1.74 & 4.40 & 06 & 154 \\
\hline 100 & 1.31 & 4.11 & 04 & 139 \\
\hline 150 & 1.08 & 2.74 & 03 & 83 \\
\hline 200 & 0.32 & 1.59 & 01 & 70 \\
\hline 250 & 0.21 & 1.35 & - & - \\
\hline CD $(0.05)$ & 0.022 & 0.04 & 1.33 & 9.95 \\
\hline S.Ed \pm & 0.01 & 0.01 & 0.67 & 4.89 \\
\hline
\end{tabular}


Table.2 Effect of $\mathrm{Cu}$ on nutrient content of the rice plant at harvest

\begin{tabular}{|c|c|c|c|c|c|c|c|}
\hline $\begin{array}{c}\text { Cu added in } \\
\text { the soil }(\mathrm{mg} \\
\left.\mathrm{kg}^{-1}\right)\end{array}$ & $\mathbf{N}$ & $\mathbf{P}$ & $\mathbf{K}$ & $\mathbf{C u}$ & $\mathbf{M n}$ & $\mathbf{F e}$ & $\mathbf{Z n}$ \\
\cline { 2 - 8 } & \multicolumn{4}{|c|}{$\mathbf{\%})$} & \multicolumn{4}{|c|}{$\left(\mathbf{m g ~ k g}^{-\mathbf{1}}\right)$} \\
\hline 0 & 1.171 & 0.424 & 2.332 & 2.81 & 33.01 & 74.97 & 12.24 \\
\hline 50 & 1.296 & 0.487 & 2.350 & 3.34 & 37.27 & 78.74 & 13.25 \\
\hline 100 & 0.874 & 0.377 & 2.246 & 5.31 & 29.71 & 72.21 & 8.51 \\
\hline 150 & 0.796 & 0.316 & 1.983 & 8.61 & 23.64 & 63.65 & 7.82 \\
\hline 200 & 0.713 & 0.211 & 1.829 & 11.51 & 21.56 & 61.38 & 7.17 \\
\hline 250 & 0.606 & 0.168 & 1.666 & 13.06 & 16.66 & 41.48 & 6.42 \\
\hline $\mathrm{CD}(0.05)$ & 0.102 & 0.048 & 0.109 & 0.343 & 3.25 & 4.38 & 0.69 \\
\hline S.Ed \pm & 0.046 & 0.022 & 0.049 & 0.156 & 1.48 & 1.99 & 0.32 \\
\hline
\end{tabular}

Fig.1 Effect of levels of $\mathrm{Cu}$ on urease enzyme activity ( $\mu \mathrm{g}$ of $\mathrm{NH}_{4}{ }^{+}-\mathrm{N}$ released $\mathrm{g}^{-1}$ soil h$^{-1}$ ) of soil at 30,60, $90 \mathrm{DAS}$ and at harvest of rice

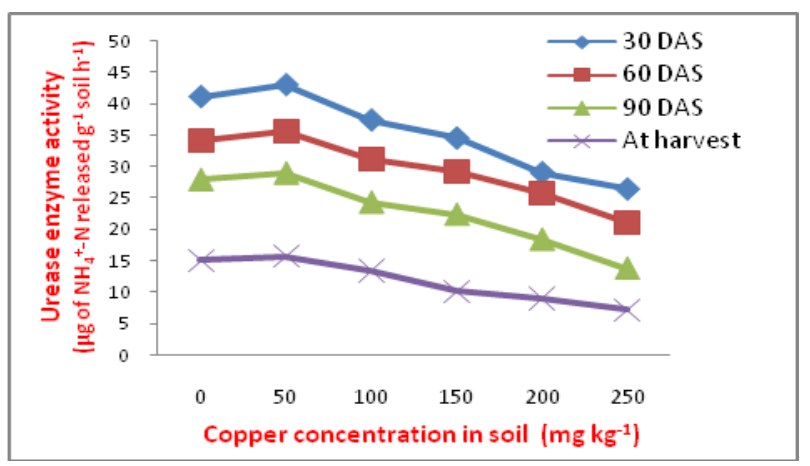

Fig.2 Effect of levels of $\mathrm{Cu}$ on dehydrogenase activity ( $\mu \mathrm{g}$ of TPF produced $\mathrm{g}^{-1}$ soil d $^{-1}$ ) of soil at $30,60,90$ DAS and at harvest of rice

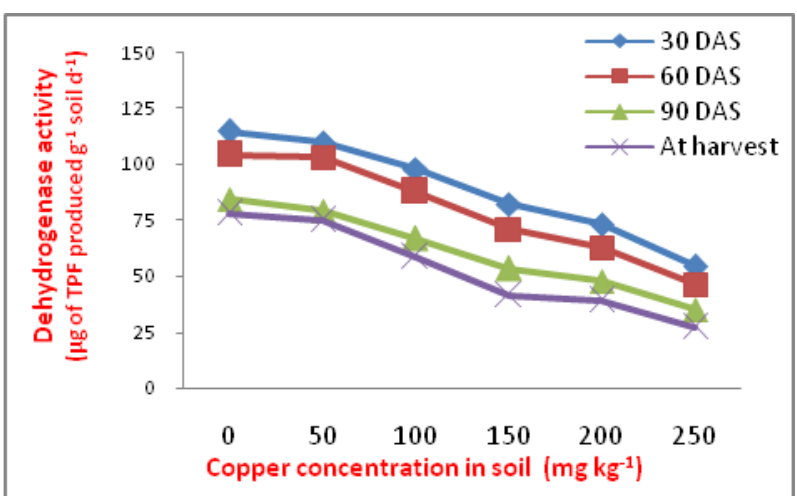


Fig.3 Effect of levels of $\mathrm{Cu}$ on acid phosphatase activity ( $\mu \mathrm{g}$ of PNP released $\mathrm{g}^{-1} \mathrm{soil} \mathrm{h}^{-1}$ ) of soil at 30, 60, $90 \mathrm{DAS}$ and at harvest of rice

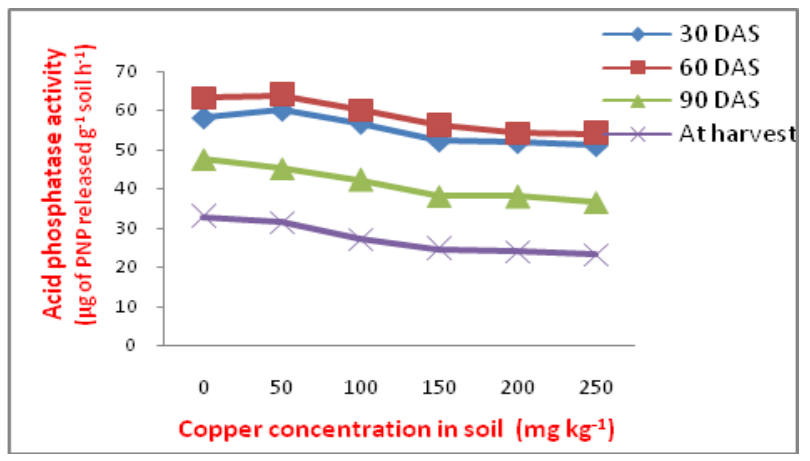

Fig.4 Effect of levels of $\mathrm{Cu}$ on alkaline phosphatase activity ( $\mu \mathrm{g}$ of PNP released $\mathrm{g}^{-1}$ soil h$^{-1}$ ) of soil at 30, 60, $90 \mathrm{DAS}$ and at harvest of rice

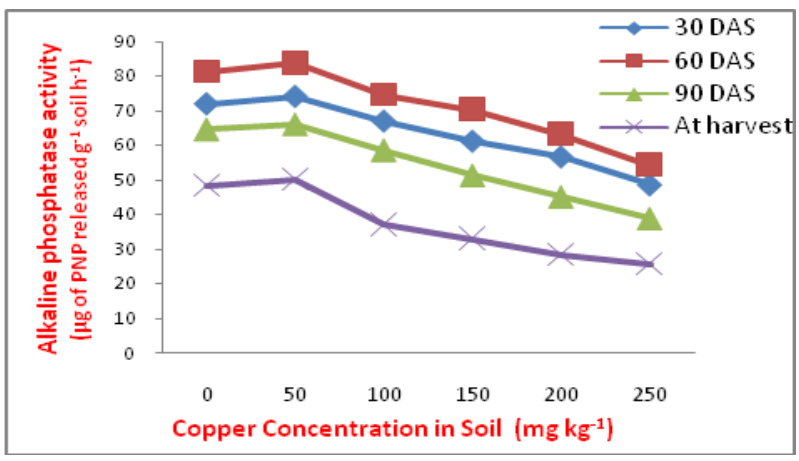

\section{Urease enzyme activity}

The enzyme urease is extracellular enzyme secreted by soil microorganisms which catalyses the hydrolysis of urea to ammonia, which subsequently transformed to $\mathrm{NH}_{4}{ }^{+}$and $\mathrm{NO}_{3}{ }^{-}$. It is ranged from 21.09 to $35.81,26.54$ to $43.15,13.86$ to 29.02 and 7.27 to $15.24 \mu \mathrm{g}$ of $\mathrm{NH}_{4}{ }^{+}$released $\mathrm{g}^{-1}$ soil $^{-1} \mathrm{~h}^{-1}$ at $30,60,90 \mathrm{DAS}$ and at harvest, respectively (Figure 1). The highest urease activity recorded with application of $\mathrm{Cu} @ 50 \mathrm{mg} \mathrm{kg}^{-1}$ at all the time intervals. The sharp increase in urease enzyme activity at 30 DAS coincide with active growth stage of the crop enhanced root activity, root proliferation and release of extracellular enzyme which resulting in higher rate of mineralisation of nutrients. The results were in conformity with the findings of Sriramachandrasekharan et al., (1997) and Srinivas et al., (2000). However, increasing $\mathrm{cu}$ concentration from 100 to $250 \mathrm{mg} \mathrm{kg}^{-1}$ decreased the enzyme activity by more than 50 percent due to decreasing population of microorganism like bacteria (Wyszkowska and Kucharski, 2003). Addition of $\mathrm{Cu} @ 250$ $\mathrm{mg} \mathrm{kg}^{-1}$ has recorded about 62.39, 55.46, 101.7 and 109.2 percent decrease in urease activity at 30, 60, 90 DAS and at harvest, respectively over control.

\section{Dehydrogenase enzyme activity}

The enzyme dehydrogenase is intracellular enzyme produced by soil microorganisms involved in degradation of carbohydrates and lipids. It is ranged from 36.48 to $64.67,44.59$ to $75.03,25.24$ to 44.58 and 17.25 to 38.18 
$\mu \mathrm{g}$ of TPF produced $\mathrm{g}^{-1}$ soil $\mathrm{d}^{-1}$ at $30,60,90$ DAS and at harvest, respectively (Figure 2). The highest dehydrogenase activity recorded in control. Increasing cu concentration from 50 to $250 \mathrm{mg} \mathrm{kg}^{-1}$ decreased the enzyme activity by more than 2 times. Addition of $\mathrm{Cu}$ @ $250 \mathrm{mg} \mathrm{kg}^{-1}$ has recorded about 77.27, 68.26, 76.62 and 121.3 percent decrease in dehydrogenase activity at 30,60,90 DAS and at harvest, respectively over control. Dehydrogenase being intracellular enzyme more sensitive to effect of excess $\mathrm{Cu}$ compared to other enzymes. $\mathrm{Cu}$ is highly toxic to micro organisms if present in excess concentration which consequently changes soil biological equilibrium with adverse effect on both soil fertility, plant development and yield. Excess $\mathrm{Cu}$ prevent the formation of red colour development product (TPF) from TTC, there is a biological conversion of TPF to colour less compound results in decrease in dehydrogenase activity (Wyszkowska, 2006).

\section{Acid and alkaline phosphatase enzyme activity}

The enzyme phosphatises breaks hemi cellular compounds of organic materials to produce humus and $\mathrm{H}_{3} \mathrm{PO}_{4}$ making $\mathrm{P}$ available to plants. Acid phosphatise activity is ranged from 55.09 to $60.26,58.09$ to 63.89 , 40.54 to 47.58 and 27.24 to $32.78 \mu \mathrm{g}$ of PNP released $\mathrm{g}^{-1}$ soil $\mathrm{h}^{-1}$ at 30, 60, $90 \mathrm{DAS}$ and at harvest, respectively (Figure 3). Alkaline phosphatise activity is ranged from 48.56 to $74.26,54.29$ to $83.75,39.08$ to 66.02 and 25.89 to $48.55 \mu \mathrm{g}$ of PNP released $\mathrm{g}^{-1}$ soil $^{-1}$ at 30, 60, 90 DAS and at harvest, respectively (Figure 4). Addition of $\mathrm{Cu}$ from 50 to $250 \mathrm{mg}$ $\mathrm{kg}^{-1}$ slightly decreased the enzyme activity over control. None of the dose of $\mathrm{Cu}$ inhibited the Acid and Alkaline Phosphatase Enzyme Activity more than 20 percent, only two higher doses i.e. 200 and 250 of $\mathrm{Cu}$ inhibited the activity more than 50 percent. Similar results reported by Wyszkowska (2005).
From these observations it can be concluded that, low $\mathrm{Cu}$ concentration had stimulatory effect on growth, dry matter yield and mineral nutrient content of rice. Application beyond these levels (100-250 mg kg-1) adversely affected the growth, dry matter yield and nutrient content. Among the enzymes studied, urease and dehydrogenases appeared to be better indicators of soil contamination with $\mathrm{Cu}$, as their activity was more strongly inhibited by $\mathrm{Cu}$ than the activity of phosphatases. $\mathrm{Cu}$ is highly toxic to micro organisms if present in excess concentration which consequently changes soil biological equilibrium with adverse effect on both soil fertility, plant development and yield.

\section{Acknowledgement}

The authors are grateful to Professor Jayashankar Telangana State Agricultural University for providing financial assistance for conducting research work under Dept. of Soil Science and Agricultural Chemistry, Regional Sugarcane and Rice Research Station during the study.

\section{References}

Ahsan, N., Lee, DG., Lee, SH., Kang, K.Y., Lee, J.J., Kim, P.J., Yoon, H.S., Kim, J.S. and Lee, B.H. 2007. Excess $\mathrm{Cu}$ induced physiological and proteomic changes in germinating rice seeds. Chemosphere, 67: 1182-1193.

Bouazizi, H., Jouili, H., Geitmann, A. and El Ferjani, E. 2008. Effect of $\mathrm{Cu}$ excess on $\mathrm{H}_{2} \mathrm{O}_{2}$ accumulation and peroxidase activities in bean roots. Acta. Biol. Hung., 59(2): 233-45.

Casida, L.E., Klein, D.A. and Santaro, J. 1964. Soil dehydrogenase activity. Soil Sci., 98: 371-376.

Gomez, K.A. and Gomez, A.A. 1984. Statistical procedures for agricultural research, John Wiley and Sons, New York. 
Klein, D.A., Loh, T.C. and Goulding. 1971. A rapid procedure to evaluate the dehydrogenase activity of soils in an organic matter. Soil Bio. and Biochem., 3: 385-387.

Lidon, F.C. and Henriques F.S. 1993. Effect of $\mathrm{Cu}$ toxicity on growth and the uptake and translocation of metals in rice plants. $J$. Plant Nutr., 16(8): 1449-1464.

Ouzounidou, G. 1994. Cu-induced changes on growth, metal content and photosynthetic function of Alyssum montanum L. plants. Environ. Exp. Bot., 34(2): 165-172.

Pancholy, K. and Rice, L-Elory. 1973. Soil enzymes in relation to old field succession: Amylase, cellulase, invertase, dehydrogenase and urease. Soil Sci. Soc. American Proc., 37: 47-49.

Pendias, A.K., Pendias, H. 2001. Trace elements in soils and plants. CRC Press, Boca Raton, FL ( $3^{\text {rd }}$ edition), pp 413.

Reddy, M.S. and Chhonkar, P.K. 1991. Urease activity in soil and flood waters as influenced by regulatory chemical and oxygen stress. J. Indian Soc. Soil Sci., 39: 84-88.

Reichman, S.M. 2002. The responses of plant to metal toxicity: A review of focusing on $\mathrm{Cu}$, manganese and zinc. Australian Minerals and Energy Environment Foundation; Melbourne, Australia, pp. 7.

Sankara Rao, V. 1989. Distribution of kinetics and some interactions of urease and phosphomonoesterase in soils. Ph D Thesis submitted to Andhra Pradesh Agricultural University, Hyderabad.

Srinivas, D., Raman, S., and Rao, P.C. 2000.
Influence of plant cover on acid and alkaline phosphatase activity in two soils of Andhra Pradesh. J. Res. ANGRAU, 28(4): 40-47.

Sriramachandrasekharan, M.V., Ramanathan, G. and Ravichandran, M. 1997. Effect of different organic manures on enzyme activities in a flooded rice soil. Oryza, 34: 39-42.

Tabatabai, M.A. and Bremner, J.M. 1969. Use of p-nitrophenyl phosphate for assay of soil phosphatase activity. Soil Bio. Bioche., 1: 301-307.

Tabatabai, M.A. and Bremner, J.M. 1972. Assay of urease activity in soils. Soil Bio. Bioche., 4: 479-489.

Wang, C., Zhang, S.H., Wang, P.F, Hou, J.Zhang, W.J., Li, W. and Lin, Z.P. 2009. The effect of excess $\mathrm{Zn}$ on mineral nutrition and antioxidative response in rapeseed seedlings. Chemosphere, 75(11): 1468-1476.

Wyszkowska, J., Kucharski, J. and Lajszner, W. 2005. Enzymatic Activities in Different Soils Contaminated with $\mathrm{Cu}$. Polish J. Environ. Stu., 14(5): 659-664.

Wyszkowska, J., Kucharski, J. and Lajszner, W. 2006. The Effects of $\mathrm{Cu}$ on Soil Biochemical Properties and Its Interaction with Other Heavy Metals. Polish J. Environ. Stud., 15(6): 927-934.

Wyszkowska J. and Kucharski J. 2003. Effect of soil conta-mination with $\mathrm{Cu}$ on its enzymatic activity and physico-chemical properties. Electronic J. Polish Agricul. Univ., Environ. Dev., 6(2).

\section{How to cite this article:}

Prabhakar Reddy, T., D. Vijaya Lakshmi, J. Kamalakar and Sambasiva Rao, Ch. 2017. Effect of Copper Contamination on Soil Biochemical Activity and Performance of Rice (Oryza sativa L.). Int.J.Curr.Microbiol.App.Sci. 6(5): 45-51. doi: http://dx.doi.org/10.20546/ijcmas.2017.605.006 